\title{
Pyocyanin from Pseudomonas induces IL-8 production through the PKC and NF-кB pathways in U937 cells
}

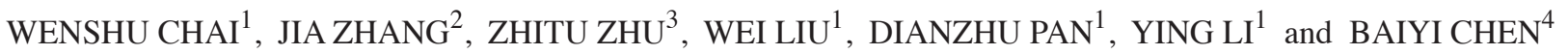 \\ ${ }^{1}$ Department of Respiratory Diseases, The First Affiliated Hospital, Liaoning Medical University, Jinzhou, Liaoning 121001; \\ ${ }^{2}$ Hebei Medical University, Shijiazhuang, Hebei 050017; ${ }^{3}$ Department of Oncology, The First Affiliated Hospital, \\ Liaoning Medical University, Jinzhou, Liaoning 121001; ${ }^{4}$ Department of Infectious Diseases, \\ The First Affiliated Hospital of Chinese Medical University, Shenyang, Liaoning 110001, P.R. China
}

Received March 1, 2013; Accepted August 15, 2013

DOI: $10.3892 / \mathrm{mmr} .2013 .1662$

\begin{abstract}
Pyocyanin, an extracellular product of Pseudomonas aeruginosa ( $P$. aeruginosa), is important in invasive pulmonary infection. Pseudomonas infections are characterized by a marked influx of polymorphonuclear cells (neutrophils). An increased release of interleukin-8 (IL-8), a potent neutrophil chemoattractant, in response to pyocyanin may contribute to the marked infiltration of neutrophils and subsequent neutrophil-mediated tissue damage observed in Pseudomonas-associated lung diseases. In order to explore the pathogenesis of pyocyanin on macrophages, we treated phorbol12-myristate-13-acetate (PMA)-differentiated U937 cells with pyocyanin in vitro and explored the expression of IL-8 using reverse transcription polymerase chain reaction (RT-PCR) and enzyme-linked immunosorbent assay (ELISA). In the present study, we also investigated the activation of protein kinase $\mathrm{C}$ $(\mathrm{PKC})$ and nuclear factor (NF) $-\kappa \mathrm{B}$ in PMA-differentiated U937 cells by western blotting and immunohistochemical methods. It was found that pyocyanin increased IL- 8 release and mRNA expression in differentiated U937 cells in a concentration- and time-dependent manner. Calphostin $\mathrm{C}$ (Cal C), a protein kinase $\mathrm{C}$ (PKC) inhibitor, and pyrrolidine dithiocarbamate (PDTC), an NF- $\kappa$ B inhibitor, blocked IL-8 expression in a concentration-dependent manner in pyocyanin-induced U937 cells. We concluded that pyocyanin promotes IL-8 secretion and mRNA expression in a concentration- and
\end{abstract}

Correspondence to: Professor Wenshu Chai, Department of Respiratory Diseases, The First Affiliated Hospital, Liaoning Medical University, No. 2 Section 5 Renmin Street, Guta, Jinzhou, Liaoning 121001, P.R. China

E-mail: cws1964@163.com

Professor Baiyi Chen, Department of Infectious Diseases, The First Affiliated Hospital of Chinese Medical University, No. 155 Nanjing Northern Street, Heping, Shenyang, Liaoning 110001, P.R. China E-mail: chenbaiyi11@163.com

Key words: pyocyanin, interleukin-8, phorbol 12-myristate 13-acetate-differentiated U937 cell, protein kinase C, nuclear factor- $\kappa \mathrm{B}$ time-dependent manner and furthermore, that the PKC and $\mathrm{NF}-\kappa \mathrm{B}$ signaling pathways may be involved in the expression of IL-8 in pyocyanin-infected PMA-differentiated U937 cells.

\section{Introduction}

Pseudomonas aeruginosa ( $P$. aeruginosa) is the most common bacterial pathogen, causing a wide range of acute and chronic infections. The bacteria are widely distributed and are characteristically multidrug resistant. Once infected, clinical therapies are complex. $P$. aeruginosa is the main cause of nosocomial infection $(1,2)$. The main successful feature in the infected host is the production of a large array of secretory factors, including proteases, exotoxins, phospholipases and pigments $(3,4)$. A number of these secretory factors have been shown to have biological effects on host cells that may contribute to the pathogenesis of $P$. aeruginosa-associated lung disease. Among these factors is the redox active phenazine derivative, pyocyanin (3-5), a cytotoxic pigment and virulence factor (6) that has been isolated from the sputum of infected patients at levels as high as $27.3 \mu \mathrm{g} / \mathrm{ml}$. One of the biological effects is a change in the expression and/or activity of cytokines (5). It has been reported that the pigment modifies several host cell responses, including the inhibition of neutrophil superoxide generation and catalase activity in human lung epithelial cells (7), the regulation of neutrophil apoptosis, the impairment of apoptotic cell engulfment $(8,9)$ and the inhibition of lymphocyte proliferation, which is responsible for the production of several important proinflammatory mediators. Thus, it is of significance to study the pathogenesis of a host infected by pyocyanin.

Alveolar macrophages are defense and inflammation regulation cells that switch on numerous mediators of inflammation and cytokines and subsequently cause acute lung injury. Thus, the intervention of $\mathrm{NF}-\kappa \mathrm{B}$ has become a therapeutic focus. However, the human medullary system U937 cell line is characteristic of monoblasts and pedomonocytes. U937 cells activated with phorbol 12-myristate 13-acetate (PMA) were induced and differentiated to form macrophages. Thus, differentiated U937 cells are the ideal model for studying human macrophages.

Pseudomonas infections are characterized by a marked influx of polymorphonuclear cells (neutrophils) and excessive inflammatory response. Chemokines are a superfamily 
of chemotactic cytokines with $>28$ recognized family members, and are important in inflammatory conditions due to their ability to attract inflammatory cells (10). They can be divided into the CXC and CC subfamilies $(11,12)$. The CXC chemokines, of which interleukin-8 (IL-8) is the prototype, predominantly act on neutrophils (11).

Previous studies have identified a secretory factor of Pseudomonas with the properties of pyocyanin that increases the release of IL- 8 by airway epithelial cells, in vitro and in vivo $(13,14)$. However, the involvement of the protein kinase $\mathrm{C}$ (PKC) and NF- $\mathrm{NB}$ pathways in Pseudomonas pyocyanininduced IL-8 production in U937 cells remained undefined. In this study, we examined the effect of pyocyanin on the release of IL-8 and the activation of NF- $\mathrm{BB}$ in U937 human monocytes stimulated with pyocyanin. Furthermore, we also observed the

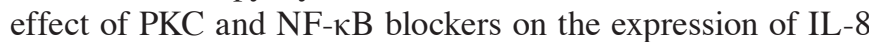
chemokines and the precise contributions of PKC kinase activation and NF- $\kappa \mathrm{B}$ transactivation to IL-8 expression of U937 cells.

\section{Materials and methods}

The present study was performed in the Department of Microbiology laboratory, Liaoning Medical University (Jinzhou, China) between October 2009 and March 2012. This study was performed with the approval of the Ethical Committee of Liaoning Medical University (Jinzhou, China; no. 201232) and conducted according to the principles of the Declaration of Helsinki. Written consent was obtained from all participants.

Chemicals and reagents. RPMI-1640, fetal bovine serum(FBS) and antibiotics were purchased from Gibco-BRL (Carlsbad, CA, USA). Stocks of the selective PKC inhibitor, calphostin C (Cal C), were purchased from Calbiochem-Behring Corp. ( $\mathrm{La}$ Jolla, CA, USA). IL-8 assay kits were purchased from R\&D Systems (Minneapolis, MN, USA). PMA was purchased from Merck Biosciences (San Diego, CA, USA). Phenazinem ethosulfate (molecular formula, $\mathrm{C}_{14} \mathrm{H}_{14} \mathrm{~N}_{2} \mathrm{O}_{4} \mathrm{~S}$ ) was from Amresco LLC (Solon, OH, USA). All other reagents were purchased from Sigma-Aldrich (St. Louis, MO, USA).

Synthesis of pyocyanin. Pyocyanin was prepared by photolysis of $700 \mathrm{mg}$ phenazine methosulphate in 1.51 of Tris buffer (0.1 M, pH 7.0) for three days, as described previously $(14,15)$. The solution was made alkaline $(\mathrm{pH}>11)$, and pyocyanin was extracted into chloroform $(5 \times 400 \mathrm{ml})$. Crude pyocyanin was chromatographed on a silica column $(60 \times 3 \mathrm{~cm})$ and eluted using chloroform and methanol $(85: 15 \mathrm{v} / \mathrm{v})$. The blue pigment was rechomatographed on fresh silica to form a product, which was judged to be pure according to high-performance liquid chromatography (HPLC; HPLC-2010; Shimadzu, Kyoto, Japan), ultraviolet (UV) absorbance (Lambda Bio40, Perkin Elemer, Waltham, MA, USA) and electrospray mass spectrometry (Finnigan $^{\mathrm{TM}} \mathrm{LCQ}^{\mathrm{TM}}$; Thermo Scientific, Waltham, MA, USA).

Cell culture and differentiation. U937 cells were purchased from ATCC (Rockville, MD, USA) and cultured at $37^{\circ} \mathrm{C}$ in a humidified atmosphere with $5 \% \mathrm{CO}_{2}$ in RPMI-1640 medium supplemented with $10 \%$ fetal calm serum (FCS) and $50 \mu \mathrm{g} / \mathrm{ml}$ gentamicin, which itself was supplemented with $4.5 \mathrm{~g} / 1$ glucose, $1 \mathrm{mM}$ sodium pyruvate and
$10 \mathrm{mM}$ 4-(2-hydroxyethyl)-1-piperazineethanesulfonic acid (HEPES). The cell culture was maintained at a cell concentration of $1 \times 10^{6}$ cells $/ \mathrm{ml}$. All cell lines were diluted one day prior to each experiment. For differentiation into macrophages, U937 cells were treated with PMA (10 nM) and allowed to adhere for $48 \mathrm{~h}$ in a $5 \% \mathrm{CO}_{2}$ tissue culture incubator at $37^{\circ} \mathrm{C}$, after which they were washed and fed with PMA-free RPMI-1640 medium.

Treatment with pyocyanin and inhibitors. PMA-differentiated U937 cells were washed; subsequently, varying concentrations of pyocyanin $(5,25$ and $50 \mu \mathrm{M})$ were added to the U937 cells with the medium, and cells were incubated in a $5 \% \mathrm{CO}_{2}$ atmosphere at $37^{\circ} \mathrm{C}$ for $24 \mathrm{~h}$. The same concentrations of pyocyanin $(50 \mu \mathrm{M})$ were added to the cell cultures for 8,16 and $24 \mathrm{~h}$, respectively. Subsequently, the culture supernatant was collected and stored in a refrigerator at $-70^{\circ} \mathrm{C}$. IL-8 concentration was measured by enzyme-linked immunosorbent assay (ELISA). RNA was subsequently extracted, and IL-8 mRNA levels were determined. In certain experiments, $\mathrm{Cal} \mathrm{C}$ and pyrrolidine dithiocarbamate (PDTC) were added with fresh medium to the U937 cells, 60 min prior to the addition of pyocyanin.

MTT assay. Cell viability was assessed using the 3-(4, 5-dimethylthiazol-2-yl)-2,5-diphenyl-tetrazolium bromide (MTT) assay kit (Sigma-Aldrich) according to the manufacturer's instructions.

Measurement of $I L-8$. Cells were cultured in 24-well tissue culture plates until they achieved $80-90 \%$ confluence. Cells were cultured in serum-free medium without growth supplements for $24 \mathrm{~h}$ prior to treatment. The medium was harvested $24 \mathrm{~h}$ following treatment and stored at $-20^{\circ} \mathrm{C}$ until they were assayed. IL- 8 levels were determined by ELISA according to the manufacturer's instructions.

Reverse transcription polymerase chain reaction ( $R T-P C R)$. Total RNA was extracted from the U937 cells as described by Chomczynski (16). At the end of the incubation period, cells were washed with $1 \mathrm{ml}$ ice-cold PBS and solubilized with $1 \mathrm{ml}$ TRIzol (Invitrogen, Carlsbad, CA, USA). RNA was treated with chloroform, centrifuged at $12,000 \mathrm{x}$ g for $15 \mathrm{~min}$ at $4^{\circ} \mathrm{C}$ and finally precipitated with ethanol. RNA was extracted and redissolved in diethylpyrocarbonate-treated water, and the outside diameter at $260 \mathrm{~nm}$ determined its concentration. In order to synthesize complementary (c)DNA, $2.5 \mu \mathrm{g}$ of RNA was resuspended in a $10-\mu 1$ final volume of the reaction buffer and incubated for $30 \mathrm{~min}$ at $42^{\circ} \mathrm{C}$. The reaction was stopped by denaturing the enzyme at $95^{\circ} \mathrm{C}$ for $5 \mathrm{~min}$. PCR was performed as follows: Synthesized cDNA $(10 \mu \mathrm{l})$ was added to $40 \mu \mathrm{l}$ of PCR mixture containing $5 \mu \mathrm{l}$ of $5 \mathrm{X}$ PCR buffer, $1.0 \mu \mathrm{l}$ of primers (GenBank accession IL-8 sense, 5'-AGATGTCAGTGCATAAAGACA-3' and antisense, 5'-TGAATTCTCAGCCCTCTTCAAAAA-3', 201 bp; and GenBank accession $\beta$-actin sense, 5'-GGCATGGGTCAGAAG GATYCC-3' and antisense, 5'-ATGTCACGCACGATTTC CCGC-3', $501 \mathrm{bp}$ ) and $0.25 \mu \mathrm{l}$ DNA polymerase. Amplification was performed with 35 cycles, which was the optimal condition for linearity and permitted semiquantitative analysis of signal strength (IL-8: temperature profile, 35 cycles of denaturation at 
$94^{\circ} \mathrm{C}$ for $45 \mathrm{sec}$, annealing at $55.3^{\circ} \mathrm{C}$ for $45 \mathrm{sec}$ and extension at $72^{\circ} \mathrm{C}$ for $1 \mathrm{~min} ; \beta$-actin: $94^{\circ} \mathrm{C}$ for $3 \mathrm{~min}, 94^{\circ} \mathrm{C}$ for $45 \mathrm{sec}, 59^{\circ} \mathrm{C}$ for $45 \mathrm{sec}, 72^{\circ} \mathrm{C}$ for $1 \mathrm{~min}, 35$ cycles, $72^{\circ} \mathrm{C}$ for $10 \mathrm{~min}$ ). Amplified PCR products were separated by electrophoresis on $1.5 \%$ agarose gel (UltraPure, Sigma-Aldrich) containing $0.05 \mu \mathrm{g} / \mathrm{ml}$ ethidium bromide. mRNA expression was visualized using a gel imaging system, analyzed using molecular analyst software (ChemiImager 5500; Alpha Innotech, Santa Clara, CA, USA) and standardized by the $\beta$-actin housekeeping gene signal to correct any variability in gel loading. The ratio between the optical density of $\beta$-actin and the test gene was calculated to evaluate relative changes in the test gene.

\section{Western blotting}

Cytosol protein preparation and western blotting. Cells were lysed in a buffer containing $20 \mathrm{mM}$ HEPES (pH 7.9), $1 \%$ Triton-X100, 0.4 M NaCl, 2.5\% glycerol, 1 mM EDTA, $1 \mathrm{mM}$ phenol methyl sulfonil fluoride (PMSF), $0.5 \mathrm{mM} \mathrm{NaF}$, $0.02 \mathrm{mg} / \mathrm{ml}$ leupeptin, $0.02 \mathrm{mg} / \mathrm{ml}$ aprotinin, $0.1 \mathrm{mg} / \mathrm{ml}$ trypsin inhibitor and $0.5 \mathrm{mM}$ dithiothreitol (DTT), as described by Maceyka et al (17). Protein content was quantitated by a Bradford assay (Pierce Biotechnology Inc., Rockford, IL, USA). Protein $(20 \mu \mathrm{l})$ of the supernatant was mixed with 5X sodium dodecyl sulfate (SDS) sample buffer $(100 \mathrm{mM}$ Tris- $\mathrm{HCl}$ (pH 6.8), 5\% SDS, $25 \%$ glycerol, $0.01 \%$ bromophenol blue) and separated on $10 \%$ SDS-polyacrylamide gels. The proteins were transferred onto $0.45-\mathrm{mm}$ nitrocellulose membranes (Schleicher \& Schuell, Dassel, Germany) in a buffer containing $25 \mathrm{mM}$ Tris- $\mathrm{HCl}(\mathrm{pH} 8.3), 0.5 \%$ SDS, $192 \mathrm{mM}$ glycine and $20 \%$ methanol. Equal protein loading was monitored by Ponceau $\mathrm{S}$ membrane staining. The membranes were blocked with $50 \mathrm{mM}$ Tris- $\mathrm{HCl}$ (pH 7.5), $150 \mathrm{mM} \mathrm{NaCl}$, $0.3 \%$ Tween-20 (TBST) containing 5\% BSA for at least $1 \mathrm{~h}$ at room temperature. Blots were subsequently incubated overnight at $4^{\circ} \mathrm{C}$ with indicated diluted primary antibodies

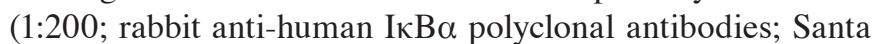
Cruz Biotechnology, Inc., Santa Cruz, CA, USA). Following three washing steps in TBST (10 min each), blots were incubated for $1 \mathrm{~h}$ at room temperature with a peroxidase-linked secondary antibody (1:2,000; goat anti-rabbit polyclonal IgG antibodies; Santa Cruz Biotechnology, Inc.). Signals were developed using 3,3'-diaminobenzidine (DAB) coloration system (Sigma-Aldrich) according to the manufacturer's instructions.

Nuclear protein preparation and western blotting. Cells were scraped into ice-cold PBS, pH 7.4, and centrifuged at $800 \mathrm{x} \mathrm{g}$ for $5 \mathrm{~min}$. The supernatant was discarded and the cells in the pellet were lysed with a buffer containing $10 \mathrm{mM}$ HEPES (pH 7.9), $10 \mathrm{mM} \mathrm{KCl,} 0.1 \mathrm{mM}$ EDTA, $0.1 \mathrm{mM}$ ethylene glycol tetraacetic acid (EGTA), 10X IGEPAL, $1.0 \mathrm{mM}$ DTT and $0.5 \mathrm{mM}$ PMSF. The cell lysate was chilled on ice for $15 \mathrm{~min}$ and subsequently centrifuged at $12,000 \mathrm{x} \mathrm{g}$ for $30 \mathrm{~min}$. The pellet was resuspended in a buffer containing $20 \mathrm{mM}$ HEPES (pH 7.9), $0.4 \mathrm{mM} \mathrm{NaCl}, 1.0 \mathrm{mM}$ EDTA, $0.1 \mathrm{mM}$ EGTA, $1.0 \mathrm{mM}$ DTT and 1.0 mM PMSF. The preparation was kept on ice for $15 \mathrm{~min}$, vortexed several times and centrifuged for $5 \mathrm{~min}\left(12,000 \mathrm{x} \mathrm{g}\right.$ at $\left.4^{\circ} \mathrm{C}\right)$. The supernatant, containing nuclear protein, was divided into aliquots, snap frozen and stored at $-80^{\circ} \mathrm{C}$. Protein concentration was measured using the Bradford reagent (Bio-Rad, Hercules, CA, USA). Proteins were separated on $10 \%$ SDS-polyacrylamide gel and transferred onto nitrocellulose membranes. Immunoreactive proteins were detected by incubating the blots with diluted p65 monoclonal antibodies (1:200; rabbit anti-human NF-кB p65; Santa Cruz Biotechnology, Inc.) at $4^{\circ} \mathrm{C}$ overnight, followed by incubation with diluted horseradish peroxidase-conjugated secondary antibody (1:2,000; goat ant-rabbit IgG antibodies; Santa Cruz Biotechnology, Inc.) and visualized with the DAB coloration system. The resulting images were analyzed with Scion Image software (Scion Corporation, Frederick, MD, USA).

Immunohistochemistry. Immunohistochemistry, using the avidin-biotin-peroxidase complex method described previously (18), was employed to examine the expression of $\mathrm{NF}-\kappa \mathrm{B}$ p65 protein following infection with pyocyanin.

Statistical analysis. Data presented are representative of three to five experiments. Unless otherwise indicated, data are expressed as the mean \pm SD. Data were analyzed using one-way analysis of variance (ANOVA) followed by the least significant difference (LSD) test for multiple comparisons. All analyses were performed using SPSS 13.0 software (SPSS Inc., Chicago, IL, USA). $\mathrm{P}<0.05$ was considered to indicate a statistically significant difference.

\section{Results}

Differentiation of U937 cells. The U937 cell of a routine subculture is a single suspension cell. Following $8 \mathrm{~h}$ of undifferentiation, the U937 cells that had been cultured in the presence of $10 \mathrm{nM}$ PMA were obtained from an independent small circular suspension cell. They had started to transform from flat elongated cells into irregular-shaped adherences; they were amoeba-like in shape and had adhered to the bottom of the container. Following $48 \mathrm{~h}$ of cultivation, $85 \%$ of the cells grew in an adherent manner. To date, differentiation of U937 cells by treatment with PMA has been accomplished.

Cell viability assay. To assess the effect of pyocyanin on cell viability, MTT assays were performed on cells incubated with a range of pyocyanin concentrations $(5-100 \mu \mathrm{M})$ for $24 \mathrm{~h}$. Cell viability was unaffected by pyocyanin $(5-75 \mu \mathrm{M})$. A 5-6\% loss of cell viability was observed at $100 \mu \mathrm{M}$ pyocyanin (data not shown). Therefore, incubation with pyocyanin at concentrations of 5-50 $\mu \mathrm{M}$ were used, producing increases over the basal level.

Effect of pyocyanin on IL-8 mRNA. In order to further explore the expression of IL- $8 \mathrm{mRNA}$ in cells infected by pyocyanin, various concentration of pyocyanin $(5,25$ and $50 \mu \mathrm{M})$ were added for the indicated times and analyzed by RT-PCR using specific primers for IL-8 according to the manufacturer's instructions. The results demonstrated that pyocyanin induced IL-8 mRNA expression in differentiated U937 cells in a concentration-dependent manner after $2 \mathrm{~h}$. The medium alone did not express IL-8 mRNA, and PMA-differentiated U937 cells produced trace amounts of IL-8 mRNA (Fig. 1).

Pyocyanin increases the release of IL-8 in PMA-differentiated U937 cells. Previous studies have identified that pyocyanin stimulates the production of IL- 8 by lung macrophage cells (19) and epithelial cells $(5,20)$. Based on the physical 

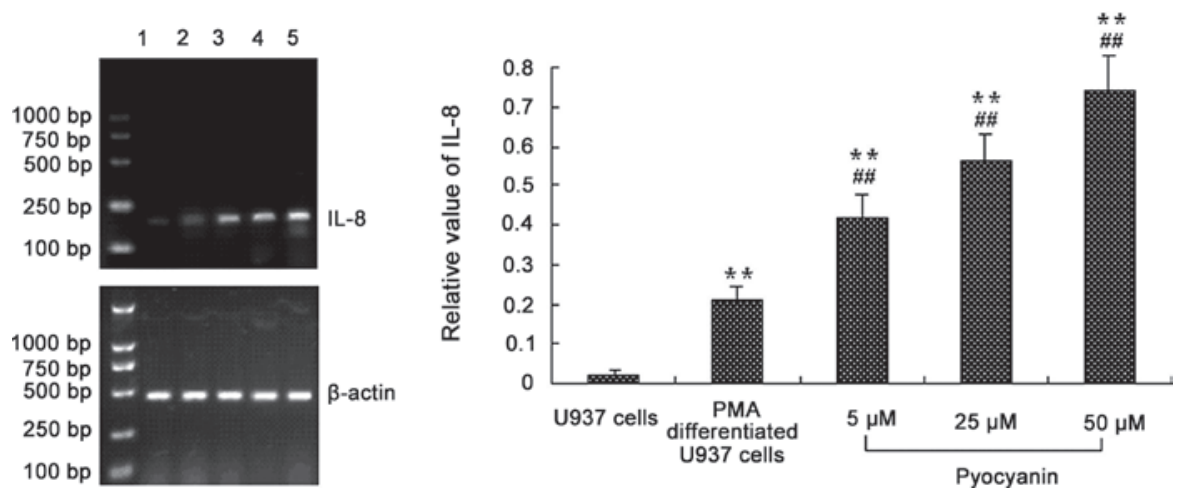

Figure 1. Effect of pyocyanin on interleukin-8 (IL-8) mRNA expression. RNA was extracted from phorbol 12-myristate 13-acetate (PMA)-differentiated U937 cells following the addition of various pyocyanin concentrations $(5,25$ and $50 \mu \mathrm{M})$ for $2 \mathrm{~h}$ and analyzed by reverse transcription polymerase chain reaction with specific primers for IL-8. 1, U937 cells; 2, PMA-differentiated U937 cells; 3 , pyocyanin $(5 \mu \mathrm{M}) ; 4$, pyocyanin $(25 \mu \mathrm{M}) ; 5$, pyocyanin $(50 \mu \mathrm{M})$; ${ }^{* *} \mathrm{P}<0.01$ compared with U937 cells; ${ }^{\# \#} \mathrm{P}<0.01$ compared with PMA-differentiated U937 cells.

A

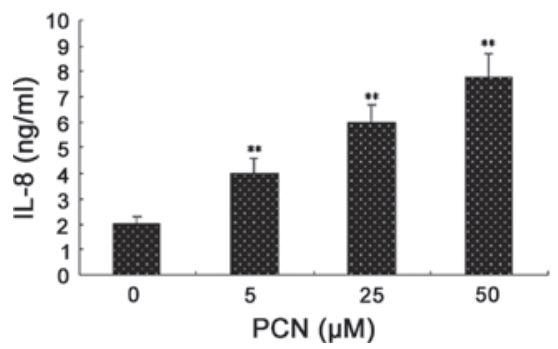

B

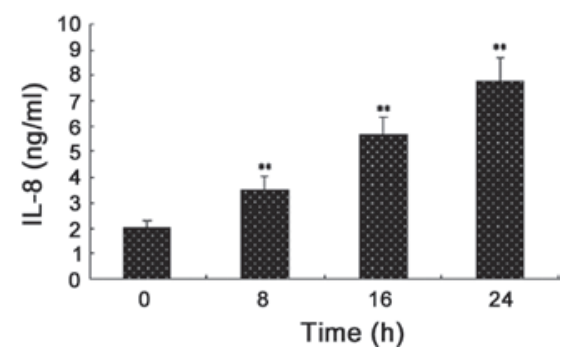

Figure 2. Pyocyanin increases interleukin-8 (IL-8) release in phorbol 12-myristate 13-acetate (PMA)-differentiated U937 cells. (A) Various concentrations of pyocyanin $(5,25$ and $50 \mu \mathrm{M})$ were added to each well for $24 \mathrm{~h}$. Supernatants were harvested in order to measure IL-8 by enzyme-linked immunosorbent assay (ELISA). (B) The same concentrations of pyocyanin $(50 \mu \mathrm{M})$ were added to the cell cultures for 8,16 and $24 \mathrm{~h}$, respectively. Supernatants were harvested in order to measure IL-8 levels by ELISA. Values are presented as the mean $\pm \mathrm{SD}$ of four independent experiments performed in triplicate. ${ }^{* * *} \mathrm{P}<0.01$ compared with PMA-differentiated U937 cells.

properties of pyocyanin, we hypothesized that pyomyacin was capable of stimulating the production of IL-8 in differentiated U937 cells. In order to assess this hypothesis, we exposed human differentiated U937 cells to purified pyocyanin and measured the release of IL-8. Following the addition of various concentrations of pyocyanin $(5,25$ and $50 \mu \mathrm{M})$ and stimulating PMA-differentiated U937 cells for $24 \mathrm{~h}$, the supernatants were collected and analyzed by ELISA. The same concentrations of pyocyanin $(50 \mu \mathrm{M})$ were added to the cell cultures for 8 , 16 and $24 \mathrm{~h}$, respectively. The results revealed that pyocyanin increased the release of IL-8 in differentiated U937 cells in a concentration- and time-dependent manner. Measurable increases in IL-8 release were observed with pyocyanin concentrations as low as $5 \mu \mathrm{M}$; a $50-\mu \mathrm{M}$ concentration showed the strongest cellular response to stimulation (Fig. 2). Increases in IL- 8 above control levels were observed as early as $8 \mathrm{~h}$ following the addition of pyocyanin $(50 \mu \mathrm{M})$, and these levels continued to increase relative to the controls between 24 and $48 \mathrm{~h}$ (data not shown). Longer times were not assessed.

Effect of PKC inhibitors on pyocyanin-induced IL-8 release. A number of studies have revealed that the PKC signaling pathway mediates a variety of stimulating factors that induce IL-8 expression. To explore the pathogenesis of pyocyanin, we hypothesized that pyocyanin may induce the expression of IL-8 in U937 cells through the PKC signaling pathway. In certain experiments, different concentrations of a PKC blocker (Cal C; 30, 100 and $300 \mathrm{nmol} / \mathrm{l}$ ) were added in a fresh medium to U937 cells 60 min prior to the addition of pyocyanin. After $24 \mathrm{~h}$, the supernatants were collected and IL-8 concentrations were detected by ELISA. The results showed that $\mathrm{Cal} C$ significantly decreased the secretion of IL-8, and as the concentration of Cal C increased, the secretion of IL-8 decreased, indicating that pyocyanin may stimulate U937 cells to express IL-8 cytokines through the PKC signaling pathway (Fig. 3).

Effect of NF- $\kappa B$ inhibitors on pyocyanin-induced IL-8 release. In order to further investigate which PKC downstream pathway is involved in pyocyanin-induced IL-8 production, varying concentrations of NF- $\mathrm{kB}$ blockers (PDTC; 50, 100 and $200 \mu \mathrm{mol} / \mathrm{l}$ ) were added in a fresh medium to PMA-differentiated U937 cells $60 \mathrm{~min}$ prior to the addition of pyocyanin. After $24 \mathrm{~h}$, the supernatants were collected and IL-8 concentrations were detected by ELISA. The results demonstrated that PDTC significantly decreased IL-8 secretion, and with increasing concentrations, IL-8 secretion decreased further, indicating that pyocyanin stimulated PMA-differentiated U937 cells to express IL-8 cytokines via the NF- $\kappa B$ signaling pathway (Fig. 4).

Effect of PKC and NF- $\mathrm{B} B$ inhibitors on pyocyanin-induced expression of $N F-\kappa B$ protein. To establish whether the NF- $\kappa \mathrm{B}$ signaling pathway participates in pyocyanin-induced IL-8 


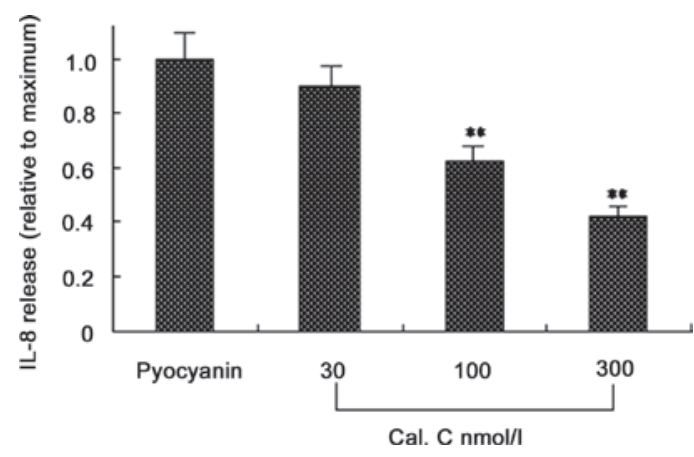

Figure 3. Effect of protein kinase $\mathrm{C}(\mathrm{PKC})$ inhibitors on pyocyanin-induced interleukin 8 (IL-8) release. Various concentrations of the PKC blocker calphostin $\mathrm{C}\left(\mathrm{Cal} \mathrm{C}, 30,100\right.$ and $\left.300 \mathrm{nmol} / \mathrm{l}^{-1}\right)$ were added to a fresh medium of phorbol 12-myristate 13-acetate (PMA)-differentiated U937 cells 60 min prior to the addition of pyocyanin. Cells were exposed to the indicated concentration of pyocyanin $(50 \mu \mathrm{M})$ for $24 \mathrm{~h}$. Supernatants were harvested in order to measure IL-8 by enzyme-linked immunosorbent assay (ELISA). ${ }^{* *} \mathrm{P}<0.01$ compared with PMA-differentiated U937 cells.

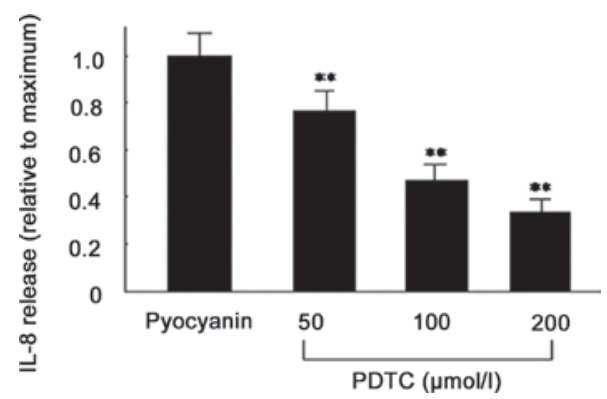

Figure 4. Effect of nuclear factor (NF)-кB inhibitors on pyocyanin-induced interleukin 8 (IL-8) release. Various concentrations of NF-кB blockers [pyrrolidine dithiocarbamate (PDTC); 50, 100 and $200 \mu \mathrm{mol} / 1$ ] were added to a fresh medium of phorbol 12-myristate 13-acetate (PMA)-differentiated U937 cells $60 \mathrm{~min}$ prior to the addition of pyocyanin. Cells were exposed to the indicated concentration of pyocyanin $(50 \mu \mathrm{M})$ for $24 \mathrm{~h}$. Supernatants were harvested in order to measure IL- 8 by enzyme-linked immunosorbent assay (ELISA). ${ }^{* *} \mathrm{P}<0.01$ compared with the pyocyanin group.

expression in PMA-differentiated U937 cells, we added pyocyanin $(50 \mu \mathrm{M})$ to stimulate PMA-differentiated U937 cells and tested the effects of PKC and NF- $\mathrm{KB}$ inhibitors. For these experiments, the cells were pretreated for $60 \mathrm{~min}$ with the PKC inhibitor, Cal C (100 nmol/l) or NF-kB inhibitor, PDTC $(100 \mu \mathrm{mol} / \mathrm{l})$ and stimulated for $1 \mathrm{~h}$ with $50 \mu \mathrm{M}$ pyocyanin; inhibitors were present throughout the experiments. Cell protein was collected and the levels of protein for NF- $\mathrm{KB}$ and $\mathrm{I} \kappa \mathrm{B}$ were assayed using western blotting, as described previously. The results showed that protein expression of NF- $\kappa B$ was more marked with the degradation of I $\mathrm{B}$ after $1 \mathrm{~h}$ in PMA-differentiated pyocyanin-induced U937 cells. The PKC inhibitor, $\mathrm{Cal} \mathrm{C}$, or NF- $\mathrm{KB}$ inhibitor, PDTC, reduced the protein expression of NF- $\kappa$ B (Fig. 5). The data shown in Fig. 5 are representative of three independent experiments.

Effect of PKC and NF- $\kappa B$ inhibitors on pyocyanin-induced $N F-\kappa B$ activation. In order to establish whether the NF- $\kappa B$ signaling pathway is involved in pyocyanin-induced IL-8 expression in PMA-differentiated U937 cells, we added pyocyanin $(50 \mu \mathrm{M})$ to stimulate PMA-differentiated U937 cells and tested the effects of PKC and NF- $\mathrm{kB}$ inhibitors.

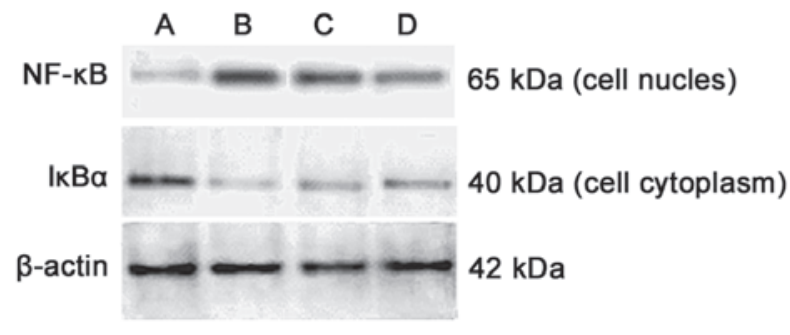
A: Control group B: Pyocyanin group
C: Cal C group D: PDTC group

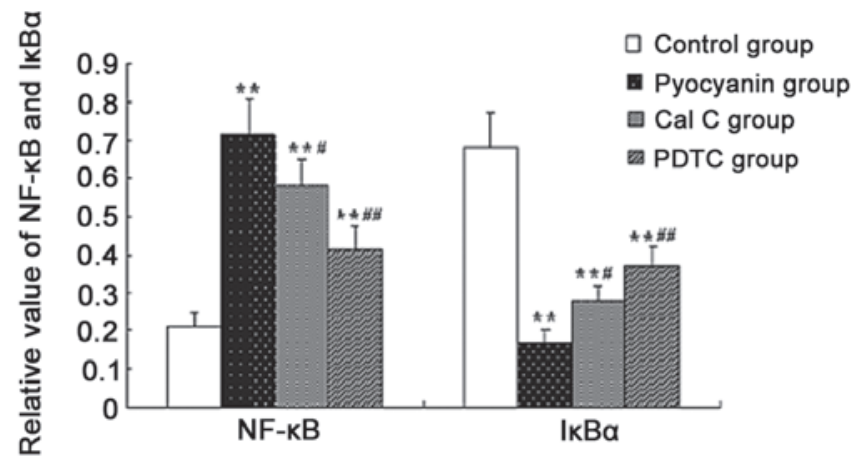

Figure 5. Effects of protein kinase $\mathrm{C}(\mathrm{PKC})$ and nuclear factor (NF)- $\kappa \mathrm{B}$ inhibitors on pyocyanin-induced NF- $\mathrm{kB}$ protein expression. For these experiments, cells were pretreated for 60 min with the $\mathrm{PKC}$ inhibitor, calphostin $\mathrm{C}$ (Cal C, $100 \mathrm{nmol} / \mathrm{l}$ ) or NF-kB inhibitor, pyrrolidine dithiocarbamate (PDTC; $100 \mu \mathrm{mol} / \mathrm{l}$ ) and subsequently stimulated for $1 \mathrm{~h}$ with $50 \mu \mathrm{m}$ pyocyanin. Cell

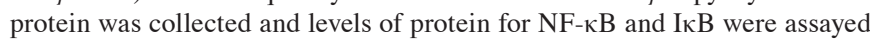
by western blotting. Representative data of three independent experiments are shown. ${ }^{\#} \mathrm{P}<0.05,{ }^{\# \#} \mathrm{P}<0.01$ compared with the pyocyanin group; ${ }^{* *} \mathrm{P}<0.01$ compared with the control group.

For these experiments, the cells were pretreated for $60 \mathrm{~min}$ with the PKC inhibitor, Cal C (100 nmol/l) or NF- $\mathrm{kB}$ inhibitor, PDTC $(100 \mu \mathrm{mol} / \mathrm{l})$, and subsequently stimulated for $1 \mathrm{~h}$ with $50 \mu \mathrm{M}$ pyocyanin. The results of immunohistochemical testing demonstrated that NF- $\mathrm{\kappa B}$ exists in the cytoplasm and, under normal conditions in its inactive form, is stained with well-distributed light dye. Increased NF- $\kappa \mathrm{B}$ activity with nuclear localization was observed following stimulation with pyocyanin. Furthermore, after PMA-differentiated U937 cells were cultured with the PKC inhibitor, Cal C, or NF- $\kappa B$ inhibitor, PDTC for 60 min prior to in vitro pyocyanin infection, a decrease in NF- $\mathrm{kB}$ nuclear translocation was observed (Fig. 6).

\section{Discussion}

Macrophages are critical in development, physiology, innate and adaptive immunity and in the pathogenesis of a variety of infectious, immunological and degenerative disease processes. They possess numerous specialized cellular functions, including phagocytosis, chemotaxis, antibody-dependent cell cytotoxicity, antigen presentation and the specific expression of a repertoire of cytokines, chemokines and cell surface markers. Several myelocytic cell lines have been established that, when differentiated with a variety of agents, make the study of these diverse functions tractable. The U937 cell line, established from a patient with histiocytic lymphoma, has properties consistent with an immature monocyte (21) and 


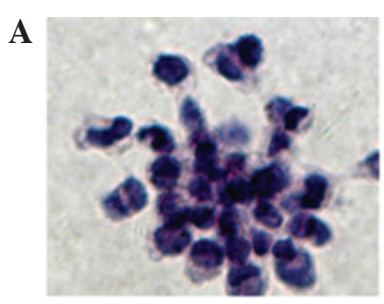

$\mathbf{D}$
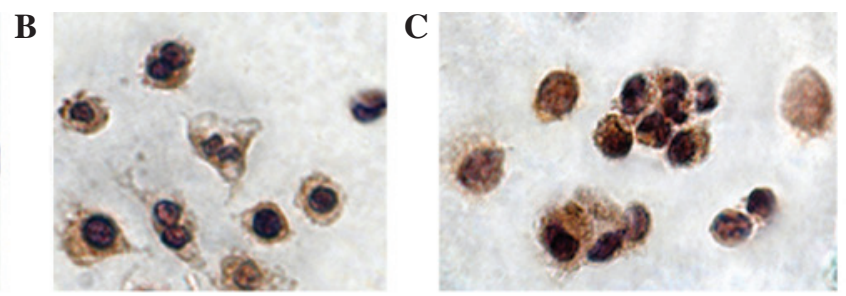

E

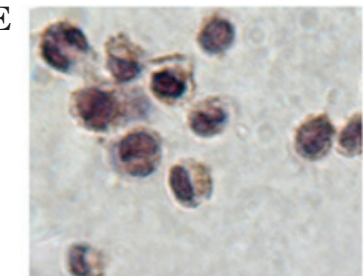

Figure 6. Effect of protein kinase $\mathrm{C}(\mathrm{PKC})$ and nuclear factor (NF)- $\kappa \mathrm{B}$ inhibitors on pyocyanin-induced NF- $\kappa \mathrm{B}$ activation. 3,3'-Diaminobenzidine dyeing was used (magnification, x400). (A) Normal negative control group; (B) normal control group; (C) pyocyanin group; (D) calphostin C (Cal C) group; (E) pyrrolidine dithiocarbamate (PDTC) group. For these experiments, cells were pretreated for 60 min with the PKC inhibitor, Cal C (100 nmol/l) or NF- $\kappa \mathrm{B}$ inhibitor, PDTC $(100 \mu \mathrm{mol} / \mathrm{l})$ and subsequently stimulated for $1 \mathrm{~h}$ with $50 \mu \mathrm{m}$ pyocyanin. The results of the immunohistochemical methods revealed that $\mathrm{NF}-\kappa \mathrm{B}$ exists in the cytoplasm, which was stained with well-distributed light dye, in its inactive form under normal conditions. Increased NF- $\mathrm{B}$ activity with nuclear localization was observed following stimulation with pyocyanin. Furthermore, after phorbol 12-myristate 13-acetate-differentiated U937 cells were cultured together with

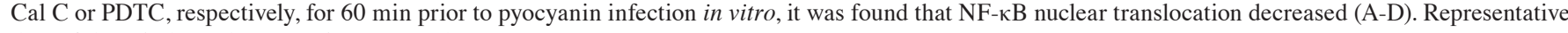
data of three independent experiments are shown.

may be induced by phorbol esters to undergo differentiation to a macrophage. Thus, U937 cell lines are useful model systems for the study of macrophage differentiation (22-24).

CXC chemokines, of which IL- 8 is the prototype, act predominantly on neutrophils and are activated in a variety of disease states and are thus likely to play an important role in $P$. aeruginosa infections. A variety of different factors are capable of inducing the production of IL-8 $(25,26)$, of which the main substances include microbial lipopolysaccharide, bacteria, viruses, cell factors, such as TNF- $\alpha$, IL-1 $\beta$ and PMA, and air pollution particles. Furthermore, UV-inactivated $P$. aeruginosa are capable of inducing the production of IL-8 and IL- 6 by mononuclear cells (27). However, the mechanism by which pyocyanin induces U937 cells to produce IL-8 remains unknown. Therefore, in this study, we examined the effect of pyocyanin on the release of IL- 8 and the activation of NF- $\kappa \mathrm{B}$ in $\mathrm{U} 937$ human monocytes stimulated with pyocyanin.

Our results demonstrated that undifferentiated U937 cells are incapable of secreting IL-8, and PMA-differentiated U937 cells are capable of secreting a small quantity of IL-8, but pyocyanin is capable of inducing IL-8 mRNA expression and IL-8 protein secretion in a concentration- and time-dependent manner in PMA-differentiated U937 cells, indicating that pyocyanin may induce inflammation.

The previously discussed results suggest that PMA provides U937 cells with the ability to produce IL-8, which demonstrates that mononuclear cells with a degree of differentiation may affect the production of IL-8. This indicates that the pyocyanin itself is an important stimulant for inflammation. However, its mechanism is unclear. Based on a review of current published literature $(4,13,14)$, the majority of studies only observe inflammation of $P$. aeruginosa bacterial products in epithelial cells and macrophages, and the lack of inflammatory response signal transduction mechanism in U937 cells. This study approaches PKC and $\mathrm{NF}-\kappa \mathrm{B}$ signal transduction and further explores the pyocyanin mechanism.
PKC is a family of protein kinase enzymes that are involved in controlling the function of other proteins through the phosphorylation of the hydroxyl groups of serine and threonine amino acid residues on these proteins. The majority of unstimulated PKC is located in the cell cytosol and, upon stimulation, translocates to the plasma membrane (28). The basic signal transduction pathway involves the allosteric activation of PKC by the intracellular messengers, diacylglycerol and calcium ions. We used pyocyanin to stimulate PMA-differentiated U937 cells and subsequently detected IL-8 expression. The result revealed that pyocyanin may induce IL-8 synthesis in a time- and concentration-dependent manner, PKC may decrease IL-8 secretion, and with increasing concentrations of Cal C, IL-8 secretion decreased, indicating that pyocyanin may stimulate PMA-differentiated U937 cells to express IL-8 cytokines via the PKC signaling pathways.

The downstream target proteins of $\mathrm{PKC}$, which have the most significant function, are the I $\mathrm{B}$ and mitogen-activated protein kinase, and phosphorylated $\mathrm{I} \kappa \mathrm{B}$ rapidly decomposes and releases small $\mathrm{NF}-\mathrm{\kappa B}$ proteins that act as nuclear transcription factors for a variety of cells. Therefore, PKC activity directly affects $\mathrm{NF}-\kappa \mathrm{B}$ activity, which is important in the transcriptional regulation of target cells as nuclear transcription factors (29).

We used pyocyanin to stimulate PMA-differentiated U937 cells and subsequently detected IL-8 expression. The results demonstrated that PDTC significantly decreased the secretion of IL-8. With increasing concentrations of PDTC, IL-8 secretion decreased, indicating that pyocyanin may stimulate PMA-differentiated U937 cells to express IL-8 cytokines through the $\mathrm{NF}-\kappa \mathrm{B}$ signaling pathways. We also observed the $\mathrm{NF}-\kappa \mathrm{B}$ p 65 nuclear translocation by using immunohistochemical methods. Additionally, quantitative analysis was performed on the cytoplasm and nuclear p65 by the application of western blotting. The experimental results agree with the classic electrophoretic mobility shift assay test results, which may be used to reflect the degree of $N F-\kappa B$ activation (21). 
The result of western blotting indicated that pyocyanin was also capable of significantly promoting the phosphorylation of $\mathrm{I} \kappa \mathrm{B} \alpha$ and activation of $\mathrm{NF}-\kappa \mathrm{B}$ following $60 \mathrm{~min}$ of infection with pyocyanin. Pretreatment of U937 cells with specific inhibitors of NF- $\mathrm{NB}$ (PDTC) and PKC (Cal C) prior to infection with pyocyanin demonstrated that PDTC and $\mathrm{Cal} \mathrm{C}$ are capable of decreasing $\mathrm{NF}-\kappa \mathrm{B}$ activation. The inhibitory role of $\mathrm{Cal} \mathrm{C}$ was weak compared with PDTC. This result demonstrated that other signaling pathways, excluding the PKC pathway, may still exist.

Immunocytochemistry results revealed that $\mathrm{NF}-\kappa \mathrm{B}$ exists in the cytoplasm, stained with well-distributed light dye, in an inactive form under normal conditions. Increased NF- $\mathrm{BB}$ activity with nuclear localization was observed following stimulation with pyocyanin. Furthermore, after PMA differentiated U937 cells were cultured together with the PKC inhibitor Cal C or NF- $\kappa$ B inhibitor PDTC, respectively, for 60 min prior to the in vitro infection with $P$. aeruginosa, $\mathrm{NF}-\kappa \mathrm{B}$ nuclear translocation was observed.

In conclusion, we observed that pyocyanin infects U937 cells in a concentration- and time-dependent manner and is capable of inducing PMA-differentiated U937 cells to produce IL- 8 by activating the PKC and NF- $\kappa \mathrm{B}$ signaling pathways. This indicates that pyocyanin from Pseudomonas has an important role in the inflammation reaction. Further studies focused on understanding the interaction between PKC and other cytokine regulators are required. Knowledge of the mechanisms by which pyocyanin induces PMA-differentiated U937 cells to produce IL-8 may provide an improved understanding and further rational approaches for the control of pyocyanin-induced inflammatory processes.

\section{Acknowledgements}

The authors would like to acknowledge the technical advice and assistance of Dr Rong Jian Su, Dr Hong Xin Wang and Mr. Zhi Hong Zong. Partial funding for this study was provided by the Department of Science and Technology, Liaoning Province (no. 201102126). This study was also partially funded by a grant from Liaoning Medical College.

\section{References}

1. Aloush V, Navon-Venezia S, Seigman-Igra Y, Cabili S and Carmeli Y: Multidrug-resistant Pseudomonas aeruginosa: risk factors and clinical impact. Antimicrob Agents Chemother 50: 43-48, 2006.

2. Tam VH, Chang KT, Abdelraouf K, et al: Prevalence, resistance mechanisms, and susceptibility of multidrug-resistant bloodstream isolates of Pseudomonas aeruginosa. Antimicrob Agents Chemother 54: 1160-1164, 2010.

3. Sadikot RT, Blackwell TS, Christman JW and Prince AS: Pathogen-host interactions in Pseudomonas aeruginosa pneumonia. Am J Respir Crit Care Med 171: 1209-1223, 2005.

4. Vinckx T, Wei Q, Matthijs S and Cornelis P: The Pseudomonas aeruginosa oxidative stress regulator OxyR influences production of pyocyanin and rhamnolipids: protective role of pyocyanin. Microbiology 156: 678-686, 2010.

5. Look DC, Stoll LL, Romig SA, Humlicek A, Britigan BE and Denning GM: Pyocyanin and its precursor phenazine-1-carboxylic acid increase IL-8 and intercellular adhesion molecule-1 expression in human airway epithelial cells by oxidant-dependent mechanisms. J Immunol 175: 4017-4023, 2005.

6. O'Malley YQ, Abdalla MY, McCormick ML, Reszka KJ, Denning GM and Britigan BE: Subcellular localization of Pseudomonas pyocyanin cytotoxicity in human lung epithelial cells. Am J Physiol Lung Cell Mol Physiol 284: L420-L430, 2003
7. O'Malley YQ, Reszka KJ, Rasmussen GT, Abdalla MY, Denning GM and Britigan BE: The Pseudomonas secretory product pyocyanin inhibits catalase activity in human lung epithelial cells. Am J Physiol Lung Cell Mol Physiol 285: L1077-L1086, 2003.

8. Prince LR, Bianchi SM, Vaughan KM, et al: Subversion of a lysosomal pathway regulating neutrophil apoptosis by a major bacterial toxin, pyocyanin. J Immunol 180: 3502-3511, 2008.

9. Bianchi SM, Prince LR, McPhillips K, et al: Impairment of apoptotic cell engulfment by pyocyanin, a toxic metabolite of Pseudomonas aeruginosa. Am J Respir Crit Care Med 177: 35-43, 2008.

10. Farberman MM, Ibricevic A, Joseph TD, et al: Effect of polarized release of CXC-chemokines from wild-type and cystic fibrosis murine airway epithelial cells. Am J Respir Cell Mol Biol 45: 221-228, 2011.

11. Mackay CR: Chemokines: immunology's high impact factors. Nat Immunol 2: 95-101, 2001

12. Power CA and Proudfoot AE: The chemokine system: novel broad-spectrum therapeutic targets. Curr Opin Pharmacol 1: 417-424, 2001.

13. Pan NY, Hui WS, Tipoe GL, et al: Inhibition of pyocyanin-potentiated IL-8 release by steroids in bronchial epithelial cells. Respir Med 100: 1614-1622, 2006.

14. Rada B, Gardina P, Myers TG and Leto TL: Reactive oxygen species mediate inflammatory cytokine release and EGFR-dependent mucin secretion in airway epithelial cells exposed to Pseudomonas pyocyanin. Mucosal Immunol 4: 158-171, 2011.

15. Elswaifi SF, Palmieri JR, Hockey KS and Rzigalinski BA: Antioxidant nanoparticles for control of infectious disease. Infect Disord Drug Targets 9: 445-452, 2009.

16. Chomczynski P: A reagent for the single-step simultaneous isolation of RNA, DNA and proteins from cell and tissue samples. Biotechniques 15: 532-537, 1993.

17. Maceyka M, Payne SG, Milstien S and Spiegel S: Sphingosine kinase, sphingosine-1-phosphate, and apoptosis. Biochim Biophys Acta 1585: 193-201, 2002.

18. Shidham VB, Qi D, Rao RN, et al: Improved immunohistochemical evaluation of micrometastases in sentinel lymph nodes of cutaneous melanoma with 'MCW melanoma cocktail' - a mixture of monoclonal antibodies to MART-1, Melan-A, and tyrosinase. BMC Cancer 3: 15, 2003.

19. Lauredo IT, Sabater JR, Ahmed A, Botvinnikova Y and Abraham WM: Mechanism of pyocyanin- and 1-hydroxyphenazine-induced lung neutrophilia in sheep airways. J Appl Physiol 85: 2298-2304, 1998.

20. Denning GM, Iyer SS, Reszka KJ, O'Malley Y, Rasmussen GT and Britigan BE: Phenazine-1-carboxylic acid, a secondary metabolite of Pseudomonas aeruginosa, alters expression of immunomodulatory proteins by human airway epithelial cells. Am J Physiol Lung Cell Mol Physiol 285: L584-L592, 2003.

21. Sundström C and Nilsson K: Establishment and characterization of a human histiocytic lymphoma cell line (U-937). Int J Cancer 17: 565-577, 1976

22. Huang ZL and Failla ML: Copper deficiency suppresses effector activities of differentiated U937 cells. J Nutr 130: 1536-1542, 2000.

23. Harris P and Ralph P: Human leukemic models of myelomonocytic development: a review of the HL-60 and U937 cell lines. J Leukocyte Biol 37: 407-422, 1985.

24. Hewison M, Brennan A, Singh-Ranger R, Walters JC, Katz DR and O'Riordan JL: The comparative role of 1,25-dihydroxycholecalciferol and phorbol esters in the differentiation of the U937 cell line. Immunology 77: 304-311,1992.

25. Delgado MA, Poschet JF and Deretic V: Nonclassical pathway of Pseudomonas aeruginosa DNA-induced interleukin-8 secretion in cystic fibrosis airway epithelial cells. Infect Immun 74: 2975-2984, 2006.

26. Venza I, Cucinotta M, Visalli M, De Grazia G, Oliva S and Teti D: Pseudomonas aeruginosa induces interleukin-8 (IL-8) gene expression in human conjunctiva through the recruitment of both RelA and CCAAT/enhancer-binding protein beta to the IL-8 promoter. J Biol Chem 284: 4191-4199, 2009.

27. Hessle CC, Andersson B and Wold AE: Gram-positive and Gram-negative bacteria elicit different patterns of pro-inflammatory cytokines in human monocytes. Cytokine 30: 311-318, 2005.

28. Steinberg SF: Structural basis of protein kinase C isoform function. Physiol Rev 88: 1341-1378, 2008.

29. Tak PP and Firestein GS: NF-kappaB: a key role in inflammatory diseases. J Clin Invest 107: 7-11, 2001. 